Hirofumi Nagahama. (2014). The Development of Values Education under the Integrated Learning Subject in the Philippines. Journal of Education and Learning. Vol. 8(2), pp. 152-163.

\title{
The Development of Values Education under the Integrated Learning Subject in the Philippines: Islamic Concepts and Peace Building
}

\author{
Hirofumi Nagahama * \\ Kyushu Women's University
}

\begin{abstract}
Values education has characterized Philippine education after the1986 People’s Power revolution. However, the understanding of values appears different in the varied regions with their distinctive cultural, historical and religious backgrounds. This research, based on classroom observations and interviews with teachers, clarifies how much their understandings on values have been diversified, especially between Christians and Muslims. On the analysis, Philippine Values education is based on the traditional values, which seem common in any part of the country, and UNESCO's framework, which seems to have universality in relation to any religious or cultural background. This paper discusses regional understandings on Values education through the analysis of class observations.
\end{abstract}

Keywords: integrated learning subject, Philippine education, cultural, historical, religious, class observation

\footnotetext{
* Hirofumi Nagahama, Faculty of Humanities, Department of Education and Psychology, Kyushu Women’s University. 1-1 Jiyugaoka, Yahatanishi-ku, Kitakyushu-shi, 807-8586, Japan Email:nghiom@yahoo.co.jp
} 


\section{Introduction}

The Philippines emphasize Values Education, which has characterized Philippine Education after the new era of the Philippine "People’s Power" Revolution in 1986. "Values" invisible and not easy to evaluate, have ever sustained Filipinos' dignity and self-esteem as a democratic country in Asia. In present, the Philippine education is under the process of introducing K-12 system, kindergarten, 6 year elementary school, 4 year junior high school, and 2 year senior high school. 2 year senior high school is a new trial to make Philippine education equivalent to those of other ASEAN developed countries. However, the curriculum is still focusing into five learning areas, Filipino, English, Science, Mathematics and other Filipino learning subjects, composed of the Philippine history and politicaleconomic system, local cultures, crafts, arts, music and games and values education. Especially the secondary-school level stresses teaching, a value of love of the country, through Philippine history and political-economic system, and international relations that asks students to develop a healthy personal and national self-identity-the aim of Philippines Values education.

Philippine Values education seems to succeed in combining the development of personality and national-identity. Strengthening of nationalism is needed to encourage the people's motivation for national development. Philippine Values education finds support, on the other hand, in UNESCO's framework of Values Education that makes the Filipino Values legitimate in school. The Philippine Department of Education explains that the integration of values education into other subjects is a "laboratory of life" or a practice environment for holistic learning and may suggest the ideal way to develop humanity and nationalism, which would never turn into a narrow sectionalism, separatism or chauvinism.

This study aims to clearly describe how values education for national identity affects minorities with different religious / regional backgrounds, and considers whether values education for national identity warrants further development at the school level. Through the results of the class observations, the paper not only describes how UNESCO's values are effecting in class teaching but also analyzes what kinds of teaching methods are implemented in each class lesson in terms of the following categories: (1) Region, and (2) Religion (Mindanao-Christian / Mindanao-Muslim).

The class observations were conducted in Tagging City, the suburb of Metro Manila, and the area where some Muslim domestic immigrants have created their communities, and Mindanao State University attached high school, Marawi City, in the ARMM (Muslim Mindanao Autonomous Region) and capital of the province of Lanao del Sur on the island of Mindanao.

\section{The Case of a Public High School in Tagig $1-8^{\text {th }}$ Grade Values Education Class}

Tagig National High School 2008/08/18 10:00-10:50"Values Education II: Reasons WHY parents separate”

(The teacher asked the students if they were okay or not. Then she told the class to speak in English as intelligently as they could.)

Teacher: And the topic today is... (writes "Values Education II: Reasons WHY parents separate) Everybody read our topic (written on the board) today. Can you understand the topic today? [Students: Yes, Ma'am.] Are you sure? [Students: Yes Ma'am.] Can you give me one reason? I would like to hear from you, (calling a student name).

Student 1: I think, one reason is a financial problem.

Teacher: Or In other words? [Students: Money problem.] Is this one of the reasons why parents separate? [Students: Yes, Ma'am.] What is this "Money Problem" all about? You will ask your parents later, "Is money a problem in the family?" (Calling a student’s name), you gave me the answer, money. Is money really one of the reasons?

Student 1: Yes Ma'am, because if you have no money, you can't feed your own family.

Teacher: Let me ask her, (calling a student name.) If your mother and father have no money, do they fight?

Student 2: Yes, ma'am.

Teacher: True? They are fighting? They are quarrelling?

Student 2: Not really, ma'am.

Teacher: (Calling other student name), why are you smiling, huh? If your mommy has only 50 pesos

${ }^{1}$ in her pocket, is she angry?

Student 3: No, Ma'am.

Teacher: Very good mother, huh? Then if your father comes home from work and ask for food, (enumerates Filipino food that costs more than 50 pesos to make) but the mommy has only 50 pesos and the father will get angry and then will the mother be angry to give the 50 pesos 
only to buy food? [Students: Yes.] And then the mother will buy tuyo ${ }^{2}$. What is tuyo? Yes, a dried fish. Is the tuyo delicious? [Students: Yes.] But the father will get angry, because he is tired from working and the food is tuyo. Will they quarrel?

Student 4: Yes, no, maybe (mixed answers).

Teacher: Usually yes? Ah, sometimes. Then, give another reason why parents separate, aside from money. I believe that money is the root of all...

Student 4: Evil.

Teacher: Have you heard about that? The phrase: 'Money is the root of all evil.' Do you believe that? Is that correct? [Students: Yes.]

Teacher: Then starting today, do not bring money anymore (joking). Another reason, aside from money. Yes, (calling student name)?

Student 5: Having misunderstanding.

Teacher: Misunderstanding. What is misunderstanding all about ? Do you think this could lead to the separation of your Mommy and Daddy? Why?

Student 5: Maybe Yes or No. Because some parents.. uhh.

Teacher: Some parents what? Yes, (calling a student name.)

Student 6: For me, misunderstanding is also a reason why parents separate because whenever parents have problems and they do not talk about it or give understanding to each other. Thus, the problem remains unsolved and it leads to separation.

Teacher: Separate already? Can't they talk this over? Or maybe there is misunderstanding because there is no..... [Students: communication.]

Teacher: communication. There is miscommunication. Maybe the other one is deaf or the other one is blind (jokingly). Maybe the other one is too busy so they cannot talk to each other. So number three aside from misunderstanding. Yes, (calling other student name).

Student 7: Having a third party.

Teacher: Boys, according to the girls, one of the reasons why parents separate is the presence of a third party. What is the third party? Let me hear the boys. Maybe Daddy is wandering already [The teacher encourages the boys to answer since not many are raising their hands. In the end, she chooses a girl student]. Yes, (calling a student name).

Student 8: Third party is another person (they love or have a relationship with) aside from their husband or wife.

Teacher: Is it wrong to love another person if you already have a husband or a wife? So Third Party is loving another person aside from their husband/wife. Is this bad? [Students say Yes.] Let us say Student A is married to Student B. And A found out that Student C is loveable. Can we say that $\mathrm{C}$ is the Third Party? [Students say Yes.] You haven't even seen the proof that they are in love with each other. (Asking Student B) will you separate already?

Student B: Maybe.

Teacher: See? You said maybe. You still love A. Will the third party destroy the relationship of the husband and the wife? [Students sayYes.] Are you sure? this "another" person may be either a man or a woman. Let's say Student B fell in love with other man. Then, you'll (B and A the make-believe husband and wife) separate? You will give him (other man) a knife? What will you do with the knife? You will kill the..? [Students: Person (jokingly).]

Teacher: Oh my. That is a sin. You will go to jail. We will go back to those reasons later. (Calling a girl student name)?

Student 9: Uh. Bad habits

Teacher: Of whom? The father or the mother? [Girls Students: Father.] Would you agree, boys? [Boys Students: No (teacher writes on the board "bad habits - vices").]

Teacher: Give me a bad example of a bad habit. Boys?

Student 10: Violence against women.

Teacher: What is violence against women? And women only?

Student 10: Child.

Teacher: Can the women hurt the men also? [Students: Yes.]

Teacher: But usually, the men hurt the... [Students answer 'women.'] There is a Republic Act wherein the rights of the women are protected. So we can say that bad habits such as violence are done by men to women. Vices, usually, men have. Correct? [Girl Students: Yes.] Correct girls? [Girls answer 'Yes.'] Correct boys? [Boys reply 'No.'] Vices like... (imitates someone smoking and drinking). [Students: Smoking and drinking alcohol.]

How about this (imitating someone dealing cards)? [Students: Gambling.] See? Why do you have these vices? Maybe you have them. [Students answer 'No.'] I heard from your classmate that she knows about gambling, smoking and drinking because she sees it in her father. Oh we pity you, we will pray 
for you so your father can change (facing the students). Another joke only. Another bad habit? [Students: Drugs.]

Teacher: Yes. But when we say drugs, it's not the (prescription) drugs like (enumerates medicines). It's prohibited drugs. For example? Yes, (calling a girl student name)?

Student 11: Marijuana, Rugby. [other students: mixed answers like: 'shabu', rugby, etc.]

Teacher: And also something we can find anywhere. Shabu. Do you know shabu (illegal drug, very common in the Philippines)? [Students: Yes, ma'am.] Will it give you a good life? [Students: No.] You can say that today but maybe someday when you will be old enough, maybe you will use that when you have problems. But remember, drugs cannot solve any your problems. Are there any other reasons children? Aside from these? Okay, you forgot this, one of the reason why parents separate is that one of the parents is gay (She reminds her students of the story of a celebrity couple who broke up because one was gay). Another reason? Yes, (Calling a boy's name)?

Student 12: Having a big family.

Teacher: Yes. Having a big family. Maybe the father or the mother can no longer bear the hardships of raising a big family (telling the story of a student with the same circumstance). Another reason? Yes, (Calling a girl name)?

Student13: Infertility.

Teacher: If the wife cannot bear children, will they separate? What about if the father is infertile/sterile? Will the wife leave the husband? What solution can you give to prevent the separation of an infertile husband/wife? [Girl: By adopting a child.] Adopting a child. Or if they are rich... Tell me what you have learned in Biology. [Students gave some answers.] Yes. Invitro Fertilization (IVF). Very good children. But if you do not have enough money and cannot go to the doctor to undergo IVF, what will you do? Adopt a dog may be one way. There are many reasons why parents separate. (If your parents separate) as their child, what will you do to prevent the separation of your Mommy and Daddy? What will you do? Let us say for example that even though they are still together, their relationship is not working anymore. You can hear them every night, shouting, causing a drama. They are fighting (adds humor). What will you do? Yes, (Calling a boy student name)?

Student 14: I would plan for a family bonding session so that their (parents) companionship will become stronger.

Teacher: Very good. Give a round of applause for him (students applaud). Family bonding because it will strengthen their companionship. Do you agree? [Students: Yes.] Example of family bonding. What will you do? Yes? [Students: Picnic.] You will go to the picnic because you will bond together parents. You will eat together and most importantly, you will talk to each other. "Mommy, do you still love Daddy? and Daddy, do you still love Mommy?" Would you ask that question? [Students: No.] Why? You should ask that question. And then your Mommy will say (does an action that implies yes) and Daddy will say (does the action again). Then you will say, "Mommy, can you seal your very nice relationship with a kiss?" and then you will have a group hug.

Student 15: I will tell them to talk calmly and try to understand the other side without shouting at each other.

Teacher: Yes. Another one? The number one thing that you should do when your parents are fighting with each other is to... [Students: Pray.] So when your parents are fighting, you kneel down and pray. "Lord, let my mother and father stay together. I don't want them to separate. Please make this happy family. I pray this in Jesus name.” Is this powerful? [Students: Yes.] Yes. You should invite your parents to go to the mass, or for the Muslim families, invite them to go to the Mosques. Where is your Mosque, (calling a Muslim student name). Is there a Mosque in Tagig close to our school? [The student says "Yes."] If you want to go to Lumos (a place where there is another Mosque), is that also okay? [The student again says "Yes."] (asking the student,) Let's say when your parents are fighting. Do they still go to the Mosque, after? [The student says "Yes."] Ah, yes? Even if they are not talking with each other?

Student 16: Yes. They will pray that God (Allah) will make ways for them to get back together.

Teacher: So Allah will make a way so that they will become a couple again. (Tells about the story of a famous boxer and his wifes who were having a rough patch in their relationship and went to church.) After going to church, they were on good terms again. So this means that prayer is a powerful weapon so that your parents will not separate. (She then asks if there were students whose parents are separated. No one raised their hands. A student said her parents were separated because her mother is working abroad. The teacher then added "One parent is 
working abroad" to the list of reasons.) When you grow up someday, when you start your own family, you will also be having a very nice family. Having a mother, a father and babies. Did you learn something today? [Students: Yes.] Would you be a good mother or father? [Students: Yes.] Would you separate from your partner just because of these (referring to the "reasons") problems? [Students: No.] If your father has an affair, what will you do?

Student 17: I would talk to them.

Teacher: What will you do if your father was a drunkard?

Student 17: I would still talking to the father.

Teacher: What if you talked with your father? Then what?

Student 17: I will explain how much alcoholic was dangerous to his body.

Teacher: Very Good. You will tell your father that abuse of alcohol causes liver cirrhosis. A smoker can die of lung cancer. A drug addict will never grow old, they would die young. Do you understand? [Yes, Ma'am.] Very good children. Yes, (calling a girl student name)?

Student 18: If it was me, I would tell father to change his old habits and to change his lifestyle. I would also tell him that there are other ways to make life more meaningful.

Teacher: Very good. What about if one of your parents was gay? If you found out your father/mother was gay and that he/she had a boyfriend/girlfriend, what would you do? Would you still love your father? [Students: Yes.] Yes. But, what would you do if one of your parents was gay? [Some students say “Accept.”] Yes. What if your parents separate? Where will you go? That is the biggest problem when parents separate. Deciding where the children will go (who will have custody of the children). (The teacher tells a story of student whose parents separated and was depressed because she couldn't decide who to go with. In the end the student quit school and stayed with his/her grandmother.)

The moral of our lesson today is number one, to pray, number two, to bond with the family, number three, to be understanding, number four, to accept. You have to accept because they are your mother and father. You cannot choose your parents. You could choose your wife/husband but not your parents. Did you like our lesson today? (She then asked again who were the students with separated parents and again, no one raised their hands.) Now, (calling a girl student name), you tell us, someday, what will you do so that you will have a strong and happy family.

Student 19: I will love my husband and children.

The teacher taught something that priests say during weddings. The saying was "No man can separate what God has put together." This applies to couples who are bound by marriage. She then goes on to say that Marriage is something sealed by God and whatever problems they may have, they should not be separated). After giving the students their homework, the teacher then ended the class.]

\section{The Case of a National High School in Tagig $2-2^{\text {nd }}$ Grade History Class}

Tagig National High School 2008/08/18 12:10-12:50“Asian History - Qin Dynasty” (Class starts with a prayer and greetings.)

Teacher: Did you go to Church last Sunday? [Students: (mixed answers)] How many are the Muslims? (Muslim students raise their hands.) Do you (the Muslim students) have church on Sundays? [Students: No. We have it on Fridays.] Who are Born Again Christians ${ }^{3}$ ? [Born Again students raise their hands.] Now listen to me, we all belong to different religious denominations. Your teacher (refers to herself) is a Born Again Christian. I would like to share with you the sermon of our pastor last Sunday. The pastors told us that there are two kinds of people who go to the temple and worship God. What are those kinds of people? One, we have what we call the "Bringers." The other one is the so-called "Carriers." The Bringers are the worshippers who are ready to worship the Lord and bring their offerings to our God to worship as a sign of love for the Lord. What are these offerings? They may be money or fruits that you want to give to the Lord that day as a sign of worship because you love the Lord. The Carriers are the group of people who have gifts. These gifts are what we call, "spiritual gifts". The Carriers are the pastors, the teachers in the church, the evangelists ${ }^{4}$ (basically the people who bring others closer to God, teach what the Lord's teaches). They are the Carriers in the church. Let me ask you now, to which do you belong, the group of the Carriers or Bringers? Who says Carriers? Raise your hand. Why are you carriers, yes, (calling a girl student name)?

Student 1: I shared the Word of God to my classmates when I was a first year student. 
Teacher: How about now?

Student 1: I will think about it (her answer).

Teacher: Ok. She told us that she's a Carrier because when she was in her first year, she shared the Word of the Lord to her classmates. But now that she's a second-year student, she's thinking of ways on how to approach you and share with you the word of God. Maybe something is wrong, (asking Student 1) do you have lots of friends here?

Student 1: Yes, Ma'am

Teacher: So start telling them the Good News. That Jesus loves them, that it's nice to live the life beautifully with the Lord. But how many says you are the Bringers? The Bringers are the ones who offer sacrifices to the Lord. Okay, (calling a Muslim student name).

Student 2: I am a Bringer, Ma'am. Because all the blessings I received from God, I should return it to him.

Teacher: Ok. Student 2 is a little bit shy. She is saying that she's a Bringer because all the blessings she receives, she gives it back to the Lord. That blessings can be financial blessings or spiritual blessings. Maybe, good relationship among families. So I would like to tell you this, even though it's not Sunday, people should still worship the Lord. We exist because God really loves us. So even though we belong to different religions, denominations, we have one goal in life. And what is that? A. The universal truth. What is that? Love. Love for the Lord. Okay? [Students: Yes, Ma'am.]

Teacher: With that, we are going to continue with our discussion. (She explained about what they would study in class: mapping of China, dynasties and Confucius. The class was an Asian history class.)

- The teacher talked about first Chinese dynasties, particularly, the Qin Dynasty. She said that dynasties have a cycle. First, the New Dynasty stage. In the New Dynasty (the one written on the board), peace was restored, new officials were elected, land was given to the farmers, irrigation and roads were fixed. Then after a few hundred years, the new Dynasty faced the next stage when the social systems became getting out of date and dynasties had not worked as a polity. At the last stage, the officials were abandoning their responsibility, control of the province was lost, taxes were elevated, and the wall of defense was destroyed.

Teacher: So what comes next? The Old dynasty will be? [Students: Corrupt.] Ok. Corruption will set in? Okay, what are those corruption? In the Old Dynasty, the leaders will not be good anymore. Will you enumerate the anomalies of the leaders of the Old Dynasty, (calling a girl student name)?

Student 2: The leaders of the Old Dynasty will set high taxes for the people so that they (the leaders) could have money for their vices (or personal wants).

Teacher: Okay. So graft and corruption will set in. Now, what comes next? Yes?

Student 3: The mandate of heaven will be lost.

Teacher: Meaning to say, the Lord is not with the leaders anymore. All these anomalies are happening because God is not with the leaders anymore. So the mandate of heaven is not with them anymore. How about our country? What is happening to our country? What do we have now in our government?

Student 4: Ma'am, corruption.

Teacher: Yes. We are experiencing corruption, (calling a girl student name)?

Student 5: We are suffering crisis.

Teacher: We are suffering crisis such as...[ Students answered 'El Nino (draught).'] What else? We are suffering shortage of? [Students answer 'Shortage of water.'] And shortage of? [Students answer 'Food.'] The price of sugar is? [Students answer 'Higher.'] Higher now. It is not stable. When you buy sugar in the store, it is much expensive nowadays. So what is the reality here? If all the anomalies are happening now, it means that God is not with the leader right now. Because if God and the mandate of heaven are with the leader right now, everyone lives comfortably, everyone is happy with the government. So let's take a look here, the mandate of heaven disappears, what will happen to the country? Ok, (calling a student name.)

Student 6: After the mandate of heaven disappears, different problems will exist such as floods, typhoons and revolution.

Teacher: There will be people who oppose the government (perform rallies, protest, etc.) because they are not content with the government anymore. So they will protest against the government. Ousting the leader would be demonstrated so that someone better could replace him/her. Ok, so this is it now, the mandate of heaven is not with the leader anymore so most likely there will be confusion or chaos. When I say chaos, disorder will set in. For example, one group is 
governing and then another group will also want to govern (thus resulting in chaos). This is what happened to China. Good thing, there was this one person who gave concern to China. Everyone was not contented, the people were not united. There was this one person who gave concern to the country. And that person was... [Students: Confucius.]

Teacher: He was the one who was really thinking how China will receive unity. So who is Confucius? I'd like to call on (calling a Muslim student name).

Student 7: (He reads who Confucius was from the book).

Teacher: So what did we get from that? Confucius was the one who taught values and how to have good relationships. Other than that? Ok, (calling a girl student name) please.

Student 8: He taught the way to good leadership.

Teacher: Other hands please? Who is Confucius? Yes, (calling a student name)?

Student 9: Confucius is one of the most popular philosophers in China.

Teacher: Okay she says that Confucius is one of the most popular philosophers in China. They considered Confucius as one of the greatest philosophers in China. Considering they have three philosophers: Confucius, Laozi and Mencius. Confucius taught that to achieve unity in one country, people must have good relationship with another. How to be a good leader according to Confucius? Remember the golden rule? What was the golden rule of Confucius? Yes, (calling a male student name)?

Student 10: Do not do unto others what you don't want others to do unto you.

Teacher: Would you like to repeat that (calling other student name)?

Student 11: The golden rule was 'do not do unto others what you don't want others to do unto you.' (The teacher then asked the students to repeat the statement over and over.)

Teacher: Ok, (calling a girl student name again who was a Born Again Christian believer), are there any similar teaching written in the Bible?

Student 12: 'Love your neighbors as you would love yourself.'

Teacher: Okay. You should love your neighbors as you would love yourself. You should love God first and then your neighbor and yourself. With this wisdom, things will get better. No rallies (demonstrations, protests), No discomfort, everyone will be happy. We live happy because everyone is thinking of the happiness of another. Now let me ask the Muslim students. Is there a verse in your Qur'an (sacred book of the Muslims) that is somewhat similar with Confucius' saying? (Calling the same Muslim student name)? You haven't hold your Qur'an? Do you read your Qur'an? [Muslim Students: Ma'am, it's very hard to read...] How many Muslims are here? Raise your hands. (Some students raise their hands.) Do you read your Qur'an? [Muslim students: Yes, Ma'am.] Yes, (calling a girl Muslim student name)?

Student 13: Ma'am, the verses written in the Qur'an are not written in the same way. It's in Arabic.

Teacher: Your Qur'an is in Arabic? But you're a Filipino. You only understand English and Filipino and yet your Qur'an is in Arabic. What does your high priest in your religion do about it? You have your class in...[Students: Madrasa (Islamic school).]

(The teacher explains that the Muslim students learn Arabic in Madrasa. She told them a story about another Muslim student who is graduating from Madrasa. She then asked who spoke Arabic. The conversation led to asking the Muslim students how to do some expressions translating into Arabic).

Teacher: So what did we learn now? Confucius is a good teacher in China. According to Confucius, in order to achieve unity, people should... [Students: love one another.] How do you extend your love to your seatmate now? (Calling a girl student name)?

Student 14: By helping him/her with her assignments.

Teacher: One more thing. You do not help your classmates by helping them cheat. Help them by letting them understand the lessons and then work independently during exams. Even though you do not know the answer, the teacher will understand. The teacher will talk to you. Maybe you have a problem so you are not able to answer the questions. Understand? [Students: Yes, Ma'am.] Okay. So with these lessons that we have discussed now, it is really important that people like us who are really different from each other, to achieve unity, we should love... ? [Students: one another] So the golden rule of Confucius.... [Students: 'Do not do unto others what you don't want others do unto you.'] Is this okay?

-Closing activities and then class ends.

\section{The Case of Mindanao 1 - $1^{\text {st }}$ Grade Values Education Class}

Mindanao State University attached Science High School 2011/03/10 8:45-9:45

Teacher: Good Morning, everyone. Ok class. Today we would like to reconsider the purpose of our subject. What is values education? 
Student 1: Refers to manners one must show. It teaches us moral values and respect to other people.

Teacher: Very good! So values education teaches on moral values. Ok more ideas? Class did you remember last time we discussed about good moral and right conduct. Am I right? [Students: Yes.] So this morning we will discuss on some of our good manners and right conduct that we practice at home. So what is a home, class? [Students: A home is a place where we live.] Ok. So what's the difference between a home and a house? When can you say it's a home or when can you say it's a house? We have just said that a home is where you lived, wherein you can see your family, right? Where the family is...?

Student 2: Happy.

Teacher: Ok, what else?

Student 3: There is love and peace.

Teacher: Ok what else? In a family there is understanding and cooperation also, right? So that is a home. Remember class, there’s a saying that goes; “there's no place like home.” What is a house? A house is just a building, right? But if in a house there is love, harmony, peace and understanding, then we can call that as a home. Did you understand the difference now, class? [Students: Yes.] So the house is just a building. Ok class, what is the part of the house? [Students: Dining room, kitchen, bedroom, comfort room etc.] Ok, like I said, there's no place like home. What do we mean by this quotation class? What is in a home?

Student 4: It is in the home wherein we can see our family.

Teacher: Right! Whereas when you go outside your home you didn't see your family. So that is the meaning of that quotation. Alright class, this morning we will discuss on good manners and right conduct at home. Take note that we are created by? [Students: Allah.]

Teacher: Ok Allah is the creator of everything. Life is time. So we value time. We don't want to miss any second of our time. Time is gold. So we have to come to the school on time. You should always budget your time. So we have to discuss good manners at home particularly in the dining room. Ok, so how many meals do we have in one day?

[Students: 3 meals. breakfast, lunch and dinner.] Ok during eating you should chew your food slowly and you should not talk when your mouth is full. Some more table manners? If somebody give food to you always say thank you. What else?

Student 5: Do not put your elbow on top of the table.

Teacher: Ok. You should also sit properly during eating. What else?

Student 6: Do not argue or quarrel during eating.

Teacher: Ok now, let's discuss good manners when meeting somebody on the street. What will you do when meeting somebody on the street? Let's demonstrate (She then made one of her students stand).

Student A: Good morning, teacher!

Teacher: Good morning! How are you?

Student A: I'm fine.

Teacher: Ok, that's the western culture of greeting somebody on the street. What about in Islamic point of view?

Student A: Assalamualaikum (May the peace and mercy of Allah be with you/ good day)!

Teacher: Aleikum-salam (Peace be upon you)!

Teacher: Note that we are Muslims. You will receive a blessing from Allah if we greet somebody we meet with peace. Aside from that if we happen to see an old people carrying heavy baggage on the street, what will you do?

Student 7: Greet them in our Islamic way of greetings and help them carrying their things.

Teacher: Ok. Other manners? What will you do when you borrow something from your classmates?

Students 8:Always ask permission. Saying, can I borrow your ball pen?

Teacher: Also always ask permission to your teacher when leaving the classroom. Ok, talking of permission. What is the prayer that we recite after eating? Can we recite that prayer? [Students recite the prayer in Arabic: "Inti fe galam.”]

Teacher: What you mean by that in English? That means, we are thanking Allah for the food and water. Now, can you also recite the prayer before eating? [Students recite the prayer in Arabic: "Bissmillah.”]

Teacher: What do you mean by that prayer in English?

Student: Thanking Allah for the food that we are about to partake.

Teacher: Anyone can we recite the prayer when going outside your house? [Students recite the prayer in Arabic: “Tawakkal to Allah.”] What is the meaning of that prayer in English? That means you are asking Allah for guidance and safety in going outside. What is the prayer before 
going to sleep? That is also another manner that Muslims have. [Students recite the prayer in Arabic: Aujubbilah himinashshaitan hirajim..."(three times).]

Teacher: Ok. What do you mean by that prayer? That means, you are asking Allah for watching you while you sleep and for waking you up in the morning. What about the prayer after waking up? [Students recite the prayer in Arabic: "Subuh" at 5 am in the morning, "Juhur" at noon, "Asal" at three pm, "Magrib"at seven pm and "Isha" at eight pm.].

Teacher: Ok. What do you mean by that prayer? Again, that means you are thanking Allah for waking you up. What about the prayer in going to the restroom? [Students recite the prayer in Arabic: "Ayeair imean wuduh."]

Teacher: What do you mean by that in English? That means you are asking Allah for protection because the devil is in the restroom. What about the prayer in after using the restroom? [Students recite the prayer in Arabic: "Aujubillah himinashshaitan hirajim.”]

Teacher: What do you mean by that prayer in English? That means you are thanking Allah for protecting you while you are in the restroom. Is there any questions class? [Students: No.] Remember class that as Muslims we should follow Qur'an, we should follow Allah. All the things that we supposed to do should be in according to the teachings of Qur'an. Remember class our stay in this world is just temporary we all die, so while we are still here on earth we should follow Allah. Ok, class. Assalamualaikum.

Students: Aleikum salam.

(After this class observation, the teacher explained why she chose the topic for me to easily demonstrate how much the students understood Islamic values as well as how much their daily lives were naturally based on the them. )

\section{The Case of Mindanao 2 - Practice teacher}

On March 12, 2011, I attended classes in the Mindanao State University attached high school program which were managed by the university senior students who were studying Values education in class. These classes demonstrated the practice teachers' original teaching methods. One future teacher said, "According to Rizal, 'The youth is the hope of the nation.' So as the youth for today we should be responsible and loving individuals. We should love our family, friends, and environment and our country as well. As a student also we should follow the right path for the future of our nation. To follow this path we acquire good knowledge and put it into practice."

Teacher: Most of the youth of today has lesser time spent talking with their parents rather than going with their friends, and that is where misunderstanding between the parents and the children starts, right? Basically, our parents know what's good for us, but we neglected that and follow our own way. Do you understand why our parents working hard all day long? [Students: Yes.]

Teacher: Do you have any hard feelings for them? Some of you say yes, some says no. In our stage we often feel that they are not fair in providing our needs. Do you think they deserved of our care? Let me ask you. What will you do to be loved by your parents?

Student 1: I will not do things against there will.

Student 2: I will do things good to make them get impress of me.

Teacher: But, actually the truth is you shouldn't have to do things to make them impress because your parents love you so much all the times. Ok. I have a story class. I guess some of you heard the story about the prodigal son.

"The story is all about the younger son of the King who told his father to get the share of his inherited fortune because he get bored in their kingdom and go into the far away land and lived an extravagant life (drinking, gambling, etc..) until to a point that he has spent all of his money and then started to face the hardships in life, like working all day long and eat like a beggar. One day he come realized to go back to their kingdom, when his father saw him in his condition he told his servants to get a nice dress to his son and they will celebrate for that his son has come back. The prodigal son told his father to be not treated that way for that he disobeyed him and to repay for that he said to his father to treat him as one of his servants, but his father accept him and treat him as the same way before."

Teacher: Talking about the story. Which part of the story that you can relate yourself? Have you disobeyed your parents also? [Students: Yes.] How many times? [Students: Many times.] But despite what we did they still love us right? Ok. What is the moral lesson of the story?

Student 1: Whatever you do your parents still loves you.

Teacher: Alright. Reflection. Looking at your life like a prodigal son, are you also disobeying your parents or having any conflicts or bad relationship with them? Who do you think is at fault is 
it your parents? Are they being unfair by having favorite son or daughter? Don't you know that we don't have any shelter to run in times of trouble except our parents? So we have to value their love by respecting, loving and caring them.

Teacher: Kindly blindfold yourself class. Ok. I want you to think about nothing at this time except your parents. What do you feel now? Can you imagine how your parents work to give your needs? How many times did you disobey them but still they forgive you? Are you showing your love to them? Are you worthy of their love? What will you do to repay their love for you?

Students: (Some students start to cry because they might feel the love of their parents.)

Teachers: (Sings a song as background music about love of parents for their children. The song is famous in the Philippines, expressing mutual love among close human relations, like families and friends).

In another school lesson, a university student teacher had his class performing an exercise of drawing pictures. In the pictures, some styles of human relations were drawn to let students consider what kinds of relations they had in their daily lives. The student teacher explained that the purpose of showing them that type of drawing was to make them aware of the real problems of the Philippines such as social (prostitution and poverty), environmental, and political (corruption) problems. By installing these into the students' minds early, he reckoned, it would provide them a sense of responsibility to someday become good Filipino citizens and good leaders for the better future of the nation. This class seemed to have similar effects to those observed in the class above at the point of calling to the students' minds the realization of how much their parents loved them.

University student teachers were composed of Muslims and Christians, but they had the same critical minds, or a consciousness that a better realization of [one]selves and [one's] human relations, and better consideration for the environment, would lead their students to a deeper understanding of social structures and their problems.

\section{The relation between Values education and Islamic concepts}

At the Mindanao State University attached high school, some teachers responded to interviews on the Values education and Integrated subjects. Some teachers explained that values education has been integrated into all subject areas. They said values which worked in the locality of Mindanao were Peace and Order. There had always been uprisings in Mindanao because the Muslim people there were fighting for themselves - they wanted their Islamic Laws to be fully implemented in their place. The teachers tended to teach mostly Islamic values which they believed could make their students peaceloving citizens. Teachers believed that peaceful-minded students would contribute to the maintenance of peace and order in the country, values which are cores of Islamic concepts.

They continued to explain that only the national government, however, has ever gained benefit from the natural resources of Mindanao. For example, the national power (electricity) source in Mindanao was coming from the lake and yet only a handful of people received its benefits. That is why the Moro-Islamic Liberation Front (MILF) was fighting for real autonomy so that people in Mindanao could have the authority to use their own natural resources. A teacher also expressed himself as a 'Filipino-Muslim' because he lived in the Philippines as a Muslim living in a "Bangsa-Moro Land (land of the Filipino Muslims);" In present, however, the autonomy is granted by the government. The Islamic idea of Bangsa as a country and the term Moros that Filipino Muslims' use to distinguish themselves now express their identity.

On October 15, 2012, the Philippine government has finally reached a framework peace agreement with MILF. In 1996, however, the government had already signed the another Final Peace Agreement with the largest group MNLF (the Moro National Liberation Front) at that time in what was supposed to be the end of the Moro armed struggle in Mindanao. On that agreement and following elections, MNLF majorities were elected as the governors and board members of the ARMM. Unfortunately, other factions within the MNLF were not satisfied with this peace pact. Their desires for complete secession from the Philippine sovereignty led to the establishment of the MILF, which became another challenge to Ramos and other governments' efforts to bring peace in Mindanao after two decades of negotiations with the MNLF.

President Benigno Aquino said, this time 2012 pace agreement admitted the establishment of Bansa Moro, that Muslims living in Mindanao had hoped from the first stage with the Philippine government in 1960's which aimed at extending power, revenues and territory granted for a new Muslim autonomous region. 
By the start of Bansa Moro, some educational reform would be remarkable in the future. However, as the principal of a high school in Mindanao elucidated, values education will be vital3, because it is through values education that they can instill moral values to the students. Teachers would inculcate into their students' minds the values that are found in the Qur'an, such as honesty, integrity, patience, love of the country, etc. They were values from the government's value framework which had been made mainly by Christians in Manila. The principal emphasized, however, that these were also significant in terms of Islamic values in order to be good citizens following the Qur'an that a Muslim should do.

He said, “We do follow the Qur'an because we love Allah, we obey Allah. To attain peace in our land, values education helps a lot. You know, peace is within us, the problem is that other people pretend to have these good values in themselves but they are not doing it, but if they do there will be no problem in Mindanao. Muslims are peace loving person that is why we want our autonomy."

Table 1. The Values Map: Core and Related Areas ${ }^{5}$

\begin{tabular}{|c|c|c|c|}
\hline 1. & & & 1997 Revised Values Education Framework \\
\hline $\begin{array}{l}\text { A } \\
\text { S }\end{array}$ & Physical & $\begin{array}{l}\text { Health and Harmony } \\
\text { with Nature }\end{array}$ & $\begin{array}{l}\text { Physical Fitness, Cleanliness, Holistic Health Reverence and Respect } \\
\text { for Life, Environmental Care }\end{array}$ \\
\hline & Spiritual & Global Spirituality & Faith in God, Inner Peace, Religious Tolerance, Unity of all \\
\hline $\begin{array}{l}\mathrm{S} \\
\mathrm{E}\end{array}$ & Intellectual & Truth and Tolerance & $\begin{array}{l}\text { Love of Truth, Openness and Respect for others Creativity, Critical } \\
\text { Thinking }\end{array}$ \\
\hline $\mathrm{L}$ & & & Future Orientation, Scientific Orientation \\
\hline $\mathrm{F}$ & Moral & Love and Goodness & $\begin{array}{l}\text { Goodness, Compassion (Caring and Sharing), Honesty/ Integrity, Trust } \\
\text { Self-worth/ Self-esteem, Personal Discipline, Courage }\end{array}$ \\
\hline 2. & Economic & Sustainable Human & Work Ethic, Economic Equity, Productivity and Quality, Responsible \\
\hline I & & Development & Consumerism \\
\hline $\mathrm{N}$ & & & $\begin{array}{l}\text { Balance between Economic and Social Development, Wise Use of } \\
\text { Resources }\end{array}$ \\
\hline $\mathrm{C}$ & & & Protection of the Environment, Entrepreneurial Spirit \\
\hline $\begin{array}{l}\mathrm{O} \\
\mathrm{M}\end{array}$ & Social & $\begin{array}{l}\text { Peace and Justice/ } \\
\text { Family }\end{array}$ & $\begin{array}{l}\text { Respect and love for One's Family, Family Solidarity, Responsible } \\
\text { Parenthood }\end{array}$ \\
\hline M & & Peace and Justice/ & Concern for Common Good, Cooperation, Fairness, Social \\
\hline $\mathrm{U}$ & & Social & Responsibility and Accountability \\
\hline $\begin{array}{l}\mathrm{N} \\
\mathrm{I}\end{array}$ & & & $\begin{array}{l}\text { Creative Goodwill, Active Non-violence, Appreciation of Diversity, } \\
\text { Respect for Human Rights }\end{array}$ \\
\hline $\mathrm{T}$ & Political & Nationalism and & International Understanding and \\
\hline $\mathrm{Y}$ & & Globalism/ & Appreciation of World Heritage \\
\hline & & Globalism & Cultural Freedom, Global Peace \\
\hline & & $\begin{array}{l}\text { Nationalism and } \\
\text { Globalism/ }\end{array}$ & $\begin{array}{l}\text { Love of Country, National Unity, Heroism and Appreciation of Heroes, } \\
\text { Committed Leadership }\end{array}$ \\
\hline & & Nationalism & $\begin{array}{l}\text { Appreciation of Cultural Heritage, Freedom and Responsibility, } \\
\text { Civic Consciousness and Active Participation, Democracy }\end{array}$ \\
\hline
\end{tabular}

The class observations in Tagig and Marawi City illustrated that the approaches and understanding of teaching values were diversified, as well as unified as the 'same' values among different regions, culture and religions. If each value had been defined as concrete concepts, they could not have succeeded as a national values framework. Especially, the adoption of UNESCO's universal concepts seemed to be working as a buffer amongst the different pedagogical approaches being adopted in the various regions. As Table 1, “The Values Map: Core and Related Areas,” indicates, Filipino Values education is composed of various universal as well as traditional values. In spite of the difficulties of dividing universal elements from traditional, a diversified society needs to unify both of them in their daily life in order to be tolerant, or open-minded towards people from any nation. The Philippines is aiming at making a 'unity in diversity,' in which values education would prove effective as an educational means or vehicle for making peace in Mindanao.

Gratitude: I would like to express my gratitude to Ms. Mercy Maceren, a Ph.D. candidate of the Graduate School of Bioresource and Bioenvironmental Resources, Kyushu University, Ms. Amanda Ramos, Senior student of the University of the Philippines, and Dr. Jeffrey Gayman, associate professor of Hokkaido University, Graduate School of International Media, Communication and Tourism Studies. Their sincere suggestions and corrections of my English and contents intensely assisted my research and writing paper motivation. Thank all of you for your kindness and friendships. 
1 It would be around 122 Japanese yen. 1 peso is about 2.43 yen. (2013/05/24)

2 Tuyo is very popular inexpensive dried salted fish in the Philippines. Tuyo is an actual meaning 'dried.' For example, check the next website: http://panlasangpinoy.com/2010/01/29/tuyo-smelly-but-lovely/

3 A sects of Christianity, like Roman Catholic, Born Agains, Inglesia ni Cristo, etc. All are Christians but considered as different groups. http://en.wikipilipinas.org/index.php?title=Born_Again_Christian (2013/05/24)

4 Evangelicalism is a theological movement, tradition, and system of beliefs, most closely associated with Protestant Christianity, which identifies with the Gospel. http://en.wikipilipinas.org/index.php?title=Category:Evangelicalism (2013/05/24)

5 Bauzon, Prisciliano T., Essentials of Values Education, Second Edition, Manila: National Book Store, 2002, pp.107-109.; UNESCO-National Commission of the Philippines Education Committee Project, Values Education for the Filipinos, 1997 Revised Version of the DECS Values Education Program, pp.6-11. 